OAK RIDGE
$\frac{\text { NATIONAL LABORATORY }}{\text { MANAGED BY UT-BATTELLE }}$
FOR THE DEPARTMENT OF ENERGY

\title{
Worldwide Historical Estimates of Leaf Area Index, 1932-2000
}

J. M. 0. Scurlock, G. P. Asner, and S. T. Gower

December 2001

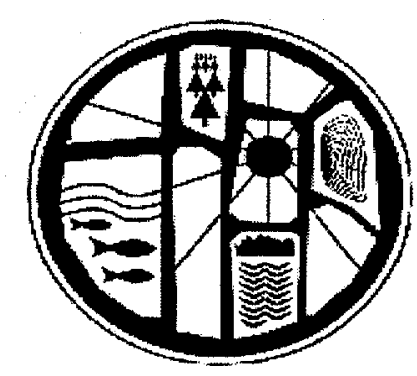




\section{DOCUMENT AVAILABILITY}

Reports produced after January 1, 1996, are generally available free via the U.S. Department of Energy (DOE) Information Bridge.

Web sits hitp://www.osti.gov/bridge

Reports produced before January 1,1996 , may be purchased by members of the public from the following source.

National Technical Information Service

5285 Port Royal Road

Springfield, VA 22161

Telephone 703-605-6000 (I-800-553-6847)

TDD 703-487-4639

Fax 703-605-6900

E-mail info@ntis.fedworld.gov

Web sits http://www.ntis.gov/supportordernowabout.htm

Reports are available to DOE employees, DOE contractors, Energy Technology Data Exchange (ETDE) representatives, and International Nuclear Information System (INIS) representatives from the following source.

Office of Scientific and Technical Information

P.O. Box 62

Oak Ridge, TN 37831

Telephone 865-576-8401

Fax 865-576-5728

E-mail reports@adonis.osti.gov

Web site http://www.osti.gov/contact.html

This report was prepared as an account of work sponsored by an agency of the United States Government. Neither the United States Government nor any agency thereof, nor any of their employees, makes any warranty, express or implied, or assumes any legal liability or responsibility for the accuracy, completeness, or usefulness of any information, apparatus, product, or process disclosed, or represents that its use would not infringe privately owned rights. Reference herein to any specific commercial product, process, or service by trade name, trademark, manufacturer, or otherwise, does not necessarily constitute or imply its endorsement, recommendation, or favoring by the United States Government or any agency thereof. The views and opinions of authors expressed herein do not necessarily state or reflect those of the United States Government or any agency thereof. 
ORNL/TM-2001/268

Environmental Sciences Division

\title{
WORLDWIDE HISTORICAL ESTIMATES \\ OF LEAF AREA INDEX, 1932-2000
}

\author{
J. M. 0. Scurlock \\ Environmental Sciences Division \\ Oak Ridge National Laboratory \\ P.O. Box 2008 \\ Oak Ridge, TN 3783 1-6407 \\ G. P. Asner \\ Department of Plant Biology \\ Carnegie Institution of Washington \\ Stanford, CA 94305 \\ S. T. Gower \\ Department of Forest Ecology and Management \\ University of Wisconsin-Madison \\ 1630 Linden Drive \\ Madison, WI 53706
}

Date Published: December 2001

This work was funded by the

U.S. National Aeronautics and Space Administration

(NASA Reference Number S-87079-F under

Interagency Agreement number 2013-P289-A1 with the U.S. Department of Energy)

Prepared by the

OAK RIDGE NATIONAL LABORATORY

Oak Ridge, Tennessee 37831

managed by

UT-BATTELLE, LLC

for the

U.S. DEPARTMENT OF ENERGY

under contract DE-AC05-00OR22725 

CONTENTS

Page
LIST OF FIGURES
LIST OF TABLES
ABSTRACT

1. INTRODUCTION, TERMS OF REFERENCE, NEED FOR THIS DATA SET $\ldots \ldots \ldots \cdots 1$

2. SIMPLE DEFINITION AND TYPICAL VALUES OF LAI …….............................. 2

3. COMMON METHODS OF DETERMINING LAI ……....................................

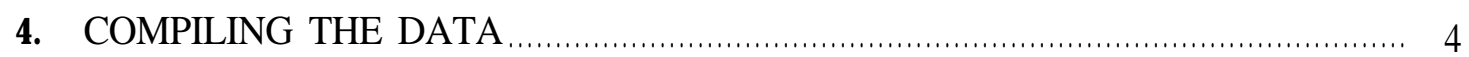

5. DATA QUALITY ASSESSMENT .............................................................. 5

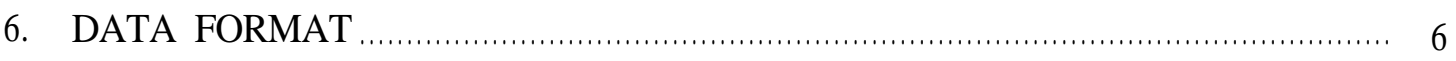

7. EXPLORATION AND ANALYSIS OF THE DATA ......................................... 8

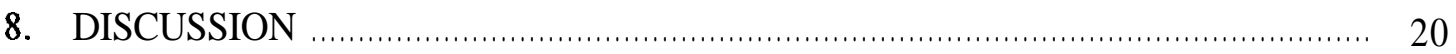

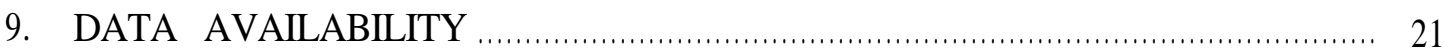

9.1 ORNL DISTRIBUTED ACTIVE ARCHIVE CENTER FOR BIOGEOCHEMICAL DYNAMICS ……......................................... 21 9.2 CAUTIONS IN USING THE DATA ……………...................................... 21

10. REFERENCES 


\section{LIST OF FIGURES}

Figure Page

$1 \quad$ Global map of study sites in the $\mathbf{L A I}$ data set ......................................... 9

2 Distribution of approximately 1000 historical estimates of LAI, summarized by biome/cover type .................................................................................... 11

3 Distribution of reported LAI values, classified by decade of publication $\ldots \ldots \ldots \ldots \ldots 12$

4 Distribution of LAI data published in the decade 1991-2000, plotted by estimatation methodology

$5 \quad$ ANPP as a function of LAI for a subset of the data for which both parameters were avalable... 


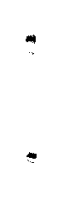




\section{LIST OF TABLES}

1 Biome/land cover classes based upon the Ecosystem Model-Data Intercomparison (Olson et al. 2001) and acronyms that appear in this data set . . . . . . 6

2 List of column headings in the LAI data set, in the order in which they occur in the data file

3 Frequency of LAI estimates for countries with more than 10 records ................. 10

$4 \quad$ Frequency of LAI records by dominant genus......................................... 10

$5 \quad$ Extended list of land validation sites for satellite remote sensing, matched to nearest sites from the Worldwide Historical LAI data set (this study). . .

6 Statistical distribution of LAI by biome, for the original data compilation, and after removal of outliers following Inter-Quartile Range (IQR) statistical analysis..... 


$$
\text { - }
$$




\begin{abstract}
Scurlock, J. M. O., G. P. Asner, and S. T. Gower. 2001. Worldwide Historical Estimates of Leaf Area Index, 1932-2000. ORNL Technical Memorandum ORNL/TM-2001/268. Oak Ridge National Laboratory, Oak Ridge, Tenn.

Approximately 1000 published estimates of leaf area index (LAI) from nearly 400 unique field sites, covering the period 1932-2000, have been compiled into a single data set. LAI is a key parameter for global and regional models of biosphere/atmosphere exchange of carbon dioxide, water vapor, and other materials. It also plays an integral role in determining the energy balance of the land surface. This data set provides a benchmark of typical values and ranges of LAI for a variety of biomes and land cover types, in support of model development and validation of satellite-derived remote sensing estimates of LAI and other vegetation parameters. The LAI data are linked to a bibliography of over 300 originalsource references.
\end{abstract}

These historic LAI data are mostly from natural and seminatural (managed) ecosystems, although some agricultural estimates are also included. Although methodologies for determining LAI have changed over the decades, it is useful to represent the inconsistencies (e.g., in maximum value reported for a particular biome) that are actually found in the scientific literature. Needleleaf (coniferous) forests are by far the most commonly measured biome/land cover types in this compilation, with $22 \%$ of the measurements from temperate evergreen needleleaf forests, and boreal evergreen needleleaf forests and crops the next most common (about 9\% each). About $40 \%$ of the records in the data set were published in the past 10 years ( 199 1-2000), with a further 20\% collected between 1981 and 1990.

Mean LAI ( \pm standard deviation), distributed between 15 biome/land cover classes, ranged from $1.31 \pm 0.85$ for deserts to $8.72 \pm 4.32$ for tree plantations, with evergreen forests (needleleaf and broadleaf) displaying the highest LAI among the natural terrestrial vegetation classes. We have identified statistical outliers in this data set, both globally and according to the different biome/land cover classes, but despite some decreases in mean LAI values reported, our overall conclusions remained the same.

This report documents the development of this data set, its contents, and its availability on the Internet from the Oak Ridge National Laboratory Distributed Active Archive Center for Biogeochemical Dynamics. Caution is advised in using these data, which were collected using a wide range of methodologies and assumptions that may not allow comparisons among sites. 


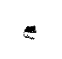

$=$ 


\section{INTRODUCTION, TERMS OF REFERENCE, NEED FOR THIS DATA SET}

Leaf area index (usually abbreviated to LAI or simply L) is broadly defined as the amount of leaf area in a vegetation canopy per unit land area. Like net primary productivity (NPP; e.g., Esser et al. 1997), LAI is a key structural characteristic of vegetation and land cover because of the role of green leaves in a wide range of biological and physical processes. Data on estimates of LAI worldwide are needed by the National Aeronautics and Space Administration (NASA) and related scientific communities investigating global change (e.g., Running and Coughlan 1988; Sellers and Schimel 1993). For example, information on typical values of LAI is required for scaling between leaf-level measurements of water vapor and $\mathrm{CO}_{2}$ conductance and flux, and estimates of these conductances and fluxes for the total vegetation-atmosphere interface (McWilliam et al. 1993). Leaf area is an important determinant of photosynthetic carbon assimilation, so the estimation of LAI provides an indicator of growth potential (Barclay 1998). LAI is also a critical variable determining the energy balance of the land surface. However, despite an abundance of individual plot and stand-based studies, there appear to be very few comprehensive reviews of LAI data in the literature. Waring (1983) discussed LAI of forests as an index of growth and canopy light competition but did not tabulate data from previous studies. Gower et al. (1999) reviewed LAI estimation techniques but again did not summarize many previous data. Schulze (1982) also discussed leaf area and canopy light interception, and provided a review of 62 estimates of LAI from 12 vegetation biome types. Asner (1998) studied canopy reflectance variation using a compilation of 29 estimates from 20 vegetation types. However, neither of these two latter studies was sufficiently comprehensive to allow for broad determinations of the range and properties of LAI values by biome, whether globally or through time.

The User Working Group of the Oak Ridge National Laboratory Distributed Active Archive Center for Biogeochemical Dynamics (ORNL) (DAAC) recommended in 1998 that the DAAC should obtain and archive vegetation data to support NASA's Earth Observing System (EOS) Land Validation activities. In particular, field data such as estimates of LAI are required to support validation of the MODIS (Moderate Resolution Imaging Spectroradiometer) sensor on the Terra satellite, launched in December 2000. Data are needed for a variety of vegetation and land cover types (e.g., grasslands and different types of mature forests) from multiple plots over an extended period of time. Such a compilation of historical LAI data can therefore provide expected values and ranges of LAI for broad spatial coverage. These data also contribute toward the DAAC's collection of regional and global data on vegetation, soils, climate, and hydrology to support NASA's Earth Science Enterprise activities on terrestrial ecosystem modeling.

Other related'paramcters, measured for the same plots or study sites, were also considered desirable by a number of advisers and reviewers of this data compilation. These included the time course (phenology) of LAI, or at least the time of year of measurement (given as month or Julian date), fPAR (fraction of photosynthetically active radiation intercepted by the canopy), albedo, fractional vegetation cover, crown allometry, leaf area density distribution within the canopy, and leaf/soil/canopy spectra. Norman and Campbell (1989) characterize LAI as just one of a number of parameters that describe canopy structure. Ideally, comprehensive metadata should accompany LAI data, such as details of methodology (direct or indirect estimation, type of instrument used, direct or diffuse radiation conditions in the case of optical methods, etc.). Unfortunately the authors found that most of these parameters and metadata are only rarely reported in the historic literature. However, at a future date it may be possible to compile a subset of the LAI data reported here for those more intensively measured and reported study sites for which additional detailed metadata and ancillary variables are available. 


\section{SIMPLE DEFINITION AND TYPICAL VALUES OF LAI}

LAI may be described most simply as:

$$
\mathrm{LAI}=s / G
$$

where $\mathrm{s}$ is the functional (green) leaf area of the canopy standing on ground area $\mathrm{G}$ (terminology after Beadle 1993). Because both $s$ and $G$ are normally measured as areas $\left(\mathrm{m}^{2}\right)$, LAI is dimensionless, although it is sometimes presented in units of $\mathrm{m}^{2} / \mathrm{m}^{2}$.

Most commonly s is measured as the projected area (e.g., after placing a sampled leaf on a horizontal surface). However, LAI may be more precisely defined in a number of different ways (see Section 3). For example, leaf area may be measured as the total surface area of leaves in a canopy. This will be equal to $2 \mathrm{~s}$ for flat leaves and greater than $2 \mathrm{~s}$ for needle-shaped and succulent leaves and photosynthetic stems. Care should be taken when making comparisons between LAI determinations that may not necessarily use the same methodology or even the same definition of LAI (Chen and Black 1992; Beadle 1993).

LAI is the major factor determining the amount of light intercepted by the plant canopy, but it varies greatly with species and canopy structure. Under optimum conditions for growth, its value for a closed canopy is related to the ability of the lower leaves in the canopy to intercept sufficient light to maintain a positive carbon balance (regardless of whether they are of the same stem, the same species, or competing/coexisting species). In general, the highest values reported previously for LAI are for particular coniferous canopies (in some cases LAI is greater than 15, although this is partly a function of how LAI is defined and measured-see Section 3). Beadle (1993) reported that maxima between 6 and 8 are typically observed for deciduous forest and between 2 and 4 for annual crops. Schulze (1982) found that typical projected LAI for most biomes (apart from desert and tundra) ranged from about 3 to 19, the

highest values being reported for boreal coniferous forest. Many types of vegetation react to stress in the environment by producing canopies with lower LAI. Thus the LAI of a particular plot compared with typical values for such a biome/land cover type may provide an indicator of stresses, such as drought, flooding, nutrient deficiency, excessive heat or cold, as well as disease, herbivory, etc.

It is important to note that LAI measured for large sample plots, satellite image pixels, or model grid cells (typically from one hectare to many square kilometers in size) comprises the average of a range of point values of LAI, often including different species and canopy types, as well as bare ground. In general, therefore, such area-weighted LAI values may be expected to display lower maximum values and lower variance than point measurements.

\section{COMMON METHODS OF DETERMINING LAI}

According to Barclay (1998), there are at least five common measures of LAI, which partly reflect the different purposes for which LAI is determined (determination of vegetation growth, estimation of potential physiological activity, study of light attenuation under plant canopies, etc.). The four most common of these are defined. 
Definition (1): Total LAI is based on the total outside area of the leaves, taking leaf shape into account, per unit area of horizontal land below the canopy.

Definition (2): One-sided LAI is usually defined as half the total LAI, even if the two sides of the leaves are not symmetrical.

Definition (3): Horizontally projected LAI is the area of "shadow" that would be cast by each leaf in the canopy with a light source at infinite distance and perpendicular to it, summed up for all leaves in the canopy.

Definition (4): Inclined projected LAI, or "silhouette" LAI, represents the projected area of leaves taking into account individual leaf inclinations. An additional fifth definition, according to Barclay (1998), is a variation on this approach, counting overlapping leaf areas only once.

Most published values of LAI appear to use definition (2) or definition (3), with an increasing number of definition (4) in the recent literature (Barclay 1998). Definition (1) is relatively rarely used (see discussion following description of methodologies). Definition (2) suffers from the problem-that the meaning of "one-sided" is unclear for coniferous needles, highly clumped foliage, or rolled leaves (Chen and Black 1992). Chen and Black (1992) suggest that the LAI of non-flat leaves should be defined as half the total intercepting area per unit ground area, and that definition (3) should be abandoned. LAI according to definition (2) may exceed LAI according to definition (3) by a factor ranging from 1.28 (hemi-circular cylinders representing conifer needles), through 1.57 (representing cylindrical green branches) to 2.0 (spheres or square bars representing highly clumped shoots and some spruce needles) (Chen and Cihlar 1996). Regrettably, many individual reports of LAI in the literature fail to provide any details of the LAI definition assumed, and a significant fraction do not even describe the methodology used.

Methodologies for ground-based estimation of LAI include

(A) destructive harvesting and direct determination of one-sided leaf area, using squared grid paper, weighing of paper replicates, or an optically based automatic area measurement system,

(B) collection and weighing of total leaf litterfall, converted to leaf area by determining specific leaf area (leaf area/leaf mass) for sub-samples;

(C) allometry (based on simple physical dimensions, such as stem diameter at breast height), using species-specific or stand-specific relationships based on detailed destructive measurement of a subsample of leaves, branches, or whole individuals;

(D) indirect contact methods, such as plumb lines and inclined point quadrats;

(E) indirect noncontact methods, such as the Decagon Ceptometer (Decagon Devices, Inc., Pullman, Washington), the LICOR LAI-2000 (Li-Cor, Inc., Lincoln, Nebraska), and analysis of hemispheric photographs.

Methodologies (A) and (B) are commonly used in conjunction with definition (2) of LAI, whereas methodologies (D) and (E) are used with definitions (3) and (4), respectively. Methodology (C) may be used with any of the LAI definitions, including definition (1), depending upon the details of the 
calibration of the allometric equations. Whereas all of these methodologies may be used for forest canopies, (A) tends to be the most common for grasslands and crops, and (D) or (C) for irregularly shaped canopies, such as shrublands. In many cases, the choice of methodology is a matter of ease of use in a particular field situation.

The user of LAI data should note that almost all of these methodologies are subject to limitations, such as sampling error (small plots, etc.) for direct determination and non-random leaf distribution and inclination in the case of the indirect methods. For example, specific leaf area in an experimental stand of sweetgum (Liquidambar styraciflua) may vary by a factor of more than two between sun and shade leaves, making it difficult to use an annual average value for the determination of LAI by methodology (B) above (Norby et al. 2001; Norby, R. J., Oak Ridge National Laboratory, personal communication, July 2001). The wide range of leaf turnover times, from less than 12 months to about 6 years, may also present problems for this methodology. Some knowledge of the dynamics of leaf area production and abscission is really required to estimate LAI (Norby, R. J., Oak Ridge National Laboratory, and S. T. Gower, University of Wisconsin-Madison, personal communication, July 2001). Leaf spatial distribution, leaf angle distribution, and the contribution of non-photosynthetic tissue to light attenuation are all complicating factors in methodology $(\mathrm{E})$, the optical determination of LAI, which was originally developed for crop canopies (Chen 1996). Strictly speaking, this methodology estimates "plant area index" (sometimes abbreviated to PAI), which includes projected stem area as well as leaves. For certain types of vegetation, instruments such as the LAI-2000 have also been found to systematically underestimate LAI compared with other methodologies (Deblonde et al. 1994; Kucharik et al. 1998; Gower et al. 1999).

Seasonal time of measurement is also an important consideration; even for evergreen canopies, there may be an important difference between annual maximum LAI and the average LAI during the growing season. LAI phenology tends to be overlooked in much of the literature.

The complexity of the radiation environment in many types of natural vegetation canopies also contributes to uncertainties in satellite-based LAI estimates, and errors in ground-based estimation of LAI only compound this problem (Chen and Cihlar 1996). However, a number of correcting factors may be applied to such indirect estimates to improve their accuracy and their comparability to direct measurement of LAI (Chen et al. 1997; Kucharik et al. 1998). The optimum strategy for collecting extensive "ground truth" LAI in the future may be to use a combination of several indirect optical methods, corrected and calibrated against a more limited number of direct estimates of LAI (Chen and Cihlar 1995).

\section{COMPILING THE DATA}

The process of compiling data of this kind includes identifying sites and sources of data; acquiring the data, metadata (information about the data), and other documentation; performing quality assessment checks; reformatting the data; and writing documentation for the entire data set. The data and documentation are then reviewed before final release to public access. Some of the initial steps in this process may be already complete for a portion of the data set, but other records may require entering anew.

The sites included in this data set represent mostly natural or seminatural ecosystems; however, some data from crops are included for comparison, and intensively managed pastures and tree plantations have been flagged where possible to distinguish them from natural or seminatural (minimally managed) grasslands 
and forests. As far as possible, the minimum criteria for inclusion of data in this compilation were the following:

- a geographical or place-name reference to the site of measurement (data related to vegetation types only were not considered)

- at least some ancillary data on vegetation type, stand age, etc., and preferably other physiological parameters such as aboveground NPP, etc.

- a citation to the source of the data

Where the geographical coordinates of the experimental site were not included in the original literature, coordinates were selected from national or regional maps, based upon site descriptions. A variety of published maps, road atlases, online maps, and online nationwide mapping software was used for this purpose.

The LAI data described here were compiled by the authors. Gower contributed a substantial data set with LAI, NPP, and references for about 700 sites. About 200 records of LAI, with references, were already available at the ORNL DAAC as a by-product of preparing the "Osnabruck" data set on NPP (Esser et al. 1997). Asner provided a data set and references for about 80 recent LAI measurements from his own work and other studies. Additional records were added as further citations and published tables of data came to light during the data compilation and quality-assurance process.

After elimination of duplicate data and doubtful or incomplete records, the data were condensed into a table of 1008 unique records from 339 known fieldsites (geographical coordinates available), with a further 69 records for which coordinates could not be estimated (i.e., about 400 locations). Each record represents a unique value reported for a particular vegetation type, treatment, or vegetation condition (maximum LAI, minimum LAI) at an individual study site. The vast majority of records $(98 \%)$ have been matched to a bibliography of over 300 original literature references, which forms a useful resource in its own right.

\section{DATA QUALITY ASSESSMENT}

Criteria for consistency in the data included the use of common systems of names, units, etc., including names of countries and assignment of biome/land cover to a consistent set of 15 classes, in addition to the original biome designation, where available. These 15 classes (Table 1) are based upon those developed for the Ecosystem Model-Data Intercomparison workshops under the auspices of the Global Primary Production Data Initiative (Olson et al. 2001; Scurlock et al. 1999). They represent a compromise between biome and land cover classes that are meaningful to ecologists, ecosystem modelers and users of satellite remote sensing data. By sorting and re-sorting the table of records in order of each variable, it was possible to check for out-of-range values and to cross-check many suspect records against the original primary literature. Geographical coordinates were converted to decimal degrees (ddd.dd), and mapped using Geographical Information System software to check for erroneous coordinates located in water bodies or other unlikely areas. 
Table 1. Biome/land cover classes based upon the Ecosystem Model-Data Intercomparison

(Olson et al. 2001) and acronyms that appear in this data set

\begin{tabular}{ll}
\hline \multicolumn{1}{c}{ Biome/land cover } & Acronym or terminology used \\
\hline Tundra, circumpolar and alpine & Tundra \\
Deserts & Desert \\
Wetlands, temperate and tropical & Wetland \\
Grasslands, temperate and tropical & Grassland \\
Crops, temperate and tropical & Crops \\
Shrubland, heath or Mediterranean-type vegetation & Shrub \\
Plantations (managed forests); temperate deciduous & Plantation \\
broadleaf, temperate evergreen needleleaf, and & \\
tropical deciduous broadleaf & \\
Forest, boreal deciduous broadleaf & Forest/BoDBL \\
Forest, boreal evergreen needleleaf & Forest/BoENL \\
Forest, boreal/temperate deciduous needleleaf & Forest/BoTeDNL \\
Forest, temperate deciduous broadleaf & Forest/TeDBL \\
Forest, temperate evergreen needleleaf & Forest/TeENL \\
Forest, temperate evergreen broadleaf & Forest/TeEBL \\
Forest, tropical deciduous broadleaf & Forest/TrDBL \\
Forest, tropical evergreen broadleaf & Forest/TrEBL \\
\hline
\end{tabular}

\section{DATA FORMAT}

The LAI data set includes column headings, such as site name, country, latitude, longitude, LAI, and many supporting variables, not all of which are available for all records (Table 2). The publicly available data consist of a large downloadable spreadsheet table (in several user-friendly proprietary formats). The bibliography of more than 300 original-source references is available as an accompanying file. References may be matched to the data records using the author name combined with the year of publication; our experience is that only the first four characters of the author name are usually required. 
Table 2. List of column headings in the LAI data set, in the order in which they occur in the data file

\begin{tabular}{|c|c|}
\hline Variable & Definition \\
\hline Sitename & Unique common name for study site, where reported \\
\hline Country & Country of study \\
\hline Latitude & $\begin{array}{l}\text { Latitude (decimal degrees) to two decimal places } \\
\text { (south is negative by convention) }\end{array}$ \\
\hline Longitude & $\begin{array}{l}\text { Longitude (decimal degrees) to two decimal places } \\
\text { (west is negative by convention) }\end{array}$ \\
\hline LAI & Leaf area index, as reported $\left(\mathrm{m}^{2} / \mathrm{m}^{2}\right.$ or dimensionless) \\
\hline Time of measurement & Season, month, occasionally exact date \\
\hline Year_LAI & $\begin{array}{l}\text { Year of original study, where reported } \\
\text { (otherwise assumed to be equal to Year_pub) }\end{array}$ \\
\hline Methodology/remarks & $\begin{array}{l}\text { Methodologies: } \\
\text { A-destructive harvest } \\
\text { B - litterfall } \\
\text { C-allometry } \\
\text { D - point quadrat/plumb line } \\
\text { E-Indirect noncontact (LAI-2000 or other) } \\
\text { X-unknown } \\
\text { Remarks where additional information given }\end{array}$ \\
\hline Biome & Biome/land cover type, as reported \\
\hline Biomecover & $\begin{array}{l}\text { Biome/land cover type assigned to one of } 15 \text { classes } \\
\text { (see Table 1) }\end{array}$ \\
\hline Dominant species & Major species/genus/family, where reported \\
\hline Author & Name of first author of original reference \\
\hline Year pub & Year of publication \\
\hline ANPP & $\begin{array}{l}\text { Aboveground net primary productivity } \\
\left(\mathrm{g} / \mathrm{m}^{2} / \text { year dry matter }\right)\end{array}$ \\
\hline BNPP & $\begin{array}{l}\text { Belowground net primary productivity } \\
\left(\mathrm{g} / \mathrm{m}^{2} / \text { year dry matter }\right)\end{array}$ \\
\hline TNPP & $\begin{array}{l}\text { Total net primary productivity (ANPP + BNPP) } \\
\left(\mathrm{g} / \mathrm{m}^{2} / \text { year dry matter }\right)\end{array}$ \\
\hline Elevation & Elevation of study site in meters, as reported \\
\hline Age & $\begin{array}{l}\text { Age of vegetation stand in years } \\
\text { (mostly reported for forests) }\end{array}$ \\
\hline Remarks/original source & $\begin{array}{l}\text { Additional remarks about peculiarities of the study; references to } \\
\text { previous or related studies }\end{array}$ \\
\hline
\end{tabular}




\section{EXPLORATION AND ANALYSIS OF THE DATA}

To characterize the LAI data set, we present summary statistics, examine the relationship between LAI and NPP, extract data for a selected set of satellite remote sensing validation sites, and conduct a prototype outlier analysis.

The distribution of the LAI measurement sites is reasonably representative of vegetation/land cover worldwide in terms of their geographical scope (Fig. 1), although it should be noted that over $40 \%$ of the records are from the United States and 15\% from Japan (Table 3). Almost two-thirds of the records $(62 \%)$ may be identified by study site name, and only $7 \%$ lack precise geographical coordinates. About half the records are dominated by 15 common plant genera, mostly forest trees such as pines $(11 \%$ of all records), although several crop genera are represented here (Table 4).

Mean values of LAI ( \pm standard deviation), distributed between 15 biome/land cover classes, ranged from $1.31 \pm 0.85$ for deserts to $8.72 \pm 4.32$ for tree plantations, with evergreen forests (needleleaf and broadleaf) displaying the highest LAI among the natural vegetation classes (Fig. 2).

Needleleaf (coniferous) forests are by far the most commonly measured biome/land cover types in this compilation, with $22 \%$ of the measurements from temperate evergreen needleleaf forests, and boreal evergreen needleleaf forests and crops the next most common (about 9\% each).

The earliest LAI record in the data set is from 1932 and the latest from 2000. When the data are plotted by decade of publication, there is a noticeable increase in the number of records (indicative of more intensive periods of study) and a decline in the mean measured value by decade (Fig. 3). The latter may reflect the tendency toward indirect methodologies for estimation of LAI (which are thought to underestimate "true" LAI for some types of canopy-see Section 3) and away from direct measurement and allometry (where small errors may propogate and result in significant overestimation of LAI). About $40 \%$ of the records in the data set were published in the past 10 years (1991-2000), with a further $20 \%$ collected between 1981 and 1990 .

Possible systematic biases in LAI estimates with different methodologies were explored by plotting the subset of data from the best-documented decade (1991-2000) according to methodology given (Fig. 4). Almost half the measurements for this decade were obtained by Methodology $C$ (allometric equations), but apart from the possibility that Methodology B (litterfall) tends to result in higher LAI estimates, there were no obvious differences between methodologies.

The relationship between aboveground net primary productivity (ANPP) and LAI was investigated for a subset of the data for which both parameters were available (excluding LAI greater than 10 to avoid allsided estimates from coniferous forests and other outliers and also excluding outliers with ANPP greater than $4000 \mathrm{~g} / \mathrm{m} 2 /$ year $)$. As might be expected, a modest but demonstrable correlation $\left(\mathrm{r}^{2}=0.33\right)$ was found between these two vegetation parameters (Fig. 5).

One possible application of the data set is shown in Table 5, where historic LAI estimates have been selected for their proximity and similarity to the NASA Land Validation sites (and other validation sites) used for calibrating satellite remote sensing of vegetation by NASA's Earth Observing System and other non-USA programs. 


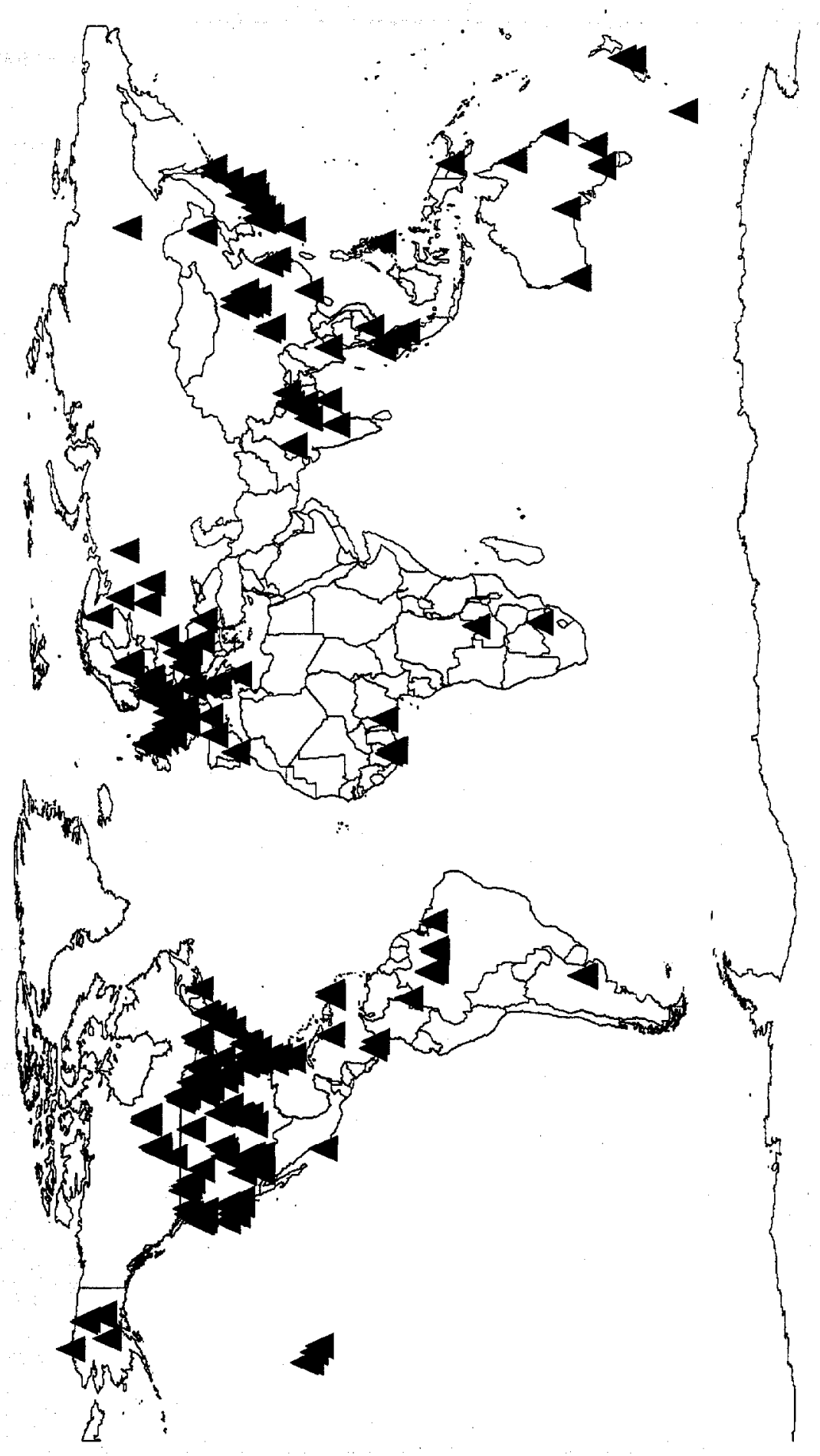

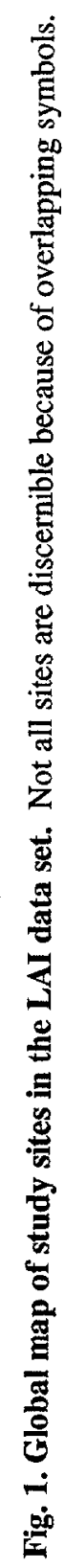


Table 3. Frequency of LAI estimates for countries with more than 10 records

\begin{tabular}{lcc}
\hline \multicolumn{1}{r}{ Country } & Frequency & Percent \\
\hline Australia & 43 & 4.3 \\
Brazil & 21 & 2.1 \\
Canada & 58 & 5.8 \\
China & 28 & 2.8 \\
France & 17 & 1.7 \\
India & 32 & 3.2 \\
Japan & 153 & 15.2 \\
New Zealand & 14 & 1.4 \\
Nepal & 11 & 1.1 \\
Puerto Rico & 13 & 1.3 \\
Russia & 22 & 2.2 \\
Sweden & 15 & 1.5 \\
U.K. & 63 & 6.3 \\
U.S.A. & 417 & 41.4 \\
Venezuela & 10 & 1.0 \\
Others & 91 & 9.0 \\
\hline
\end{tabular}

Table 4. Frequency of LAI records by dominant genus

\begin{tabular}{lcc}
\hline \multicolumn{1}{c}{ Genus } & Frequency & Percent \\
\hline Acer & 14 & 1.4 \\
Eucalymanturia & 12 & 13.3 \\
Fagus & 16 & 1.6 \\
Helianthus & 17 & 1.7 \\
Metrosideros & 17 & 1.7 \\
Picea & 71 & 7.0 \\
Pinus & 111 & 11.0 \\
Populus & 48 & 4.8 \\
Pseudotsuga & 18 & 1.8 \\
Quercus & 50 & 5.0 \\
Shorea & 14 & 1.4 \\
Triticum & 19 & 1.9 \\
Vicia & 10 & 1.0 \\
Zea & 15 & 1.5 \\
Others & 223 & 22.1 \\
Genus not reported & 329 & 32.6 \\
Total & 1008 & 100.0 \\
\hline
\end{tabular}




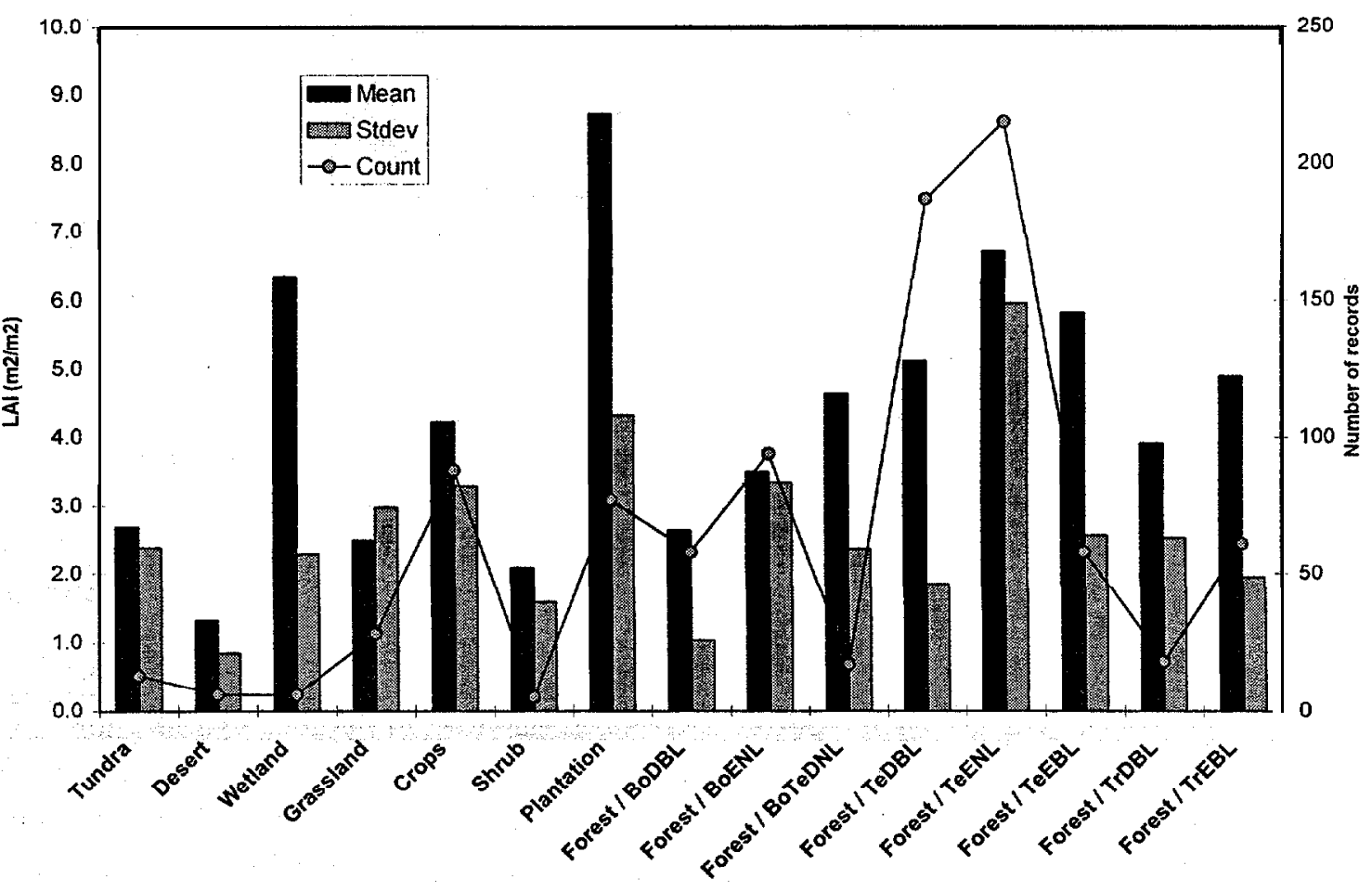

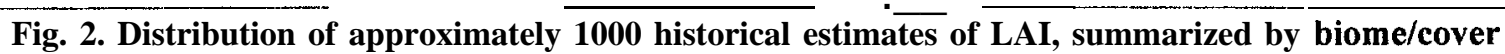
type. See Table 1(b) for explanation of abbreviated biome names. 


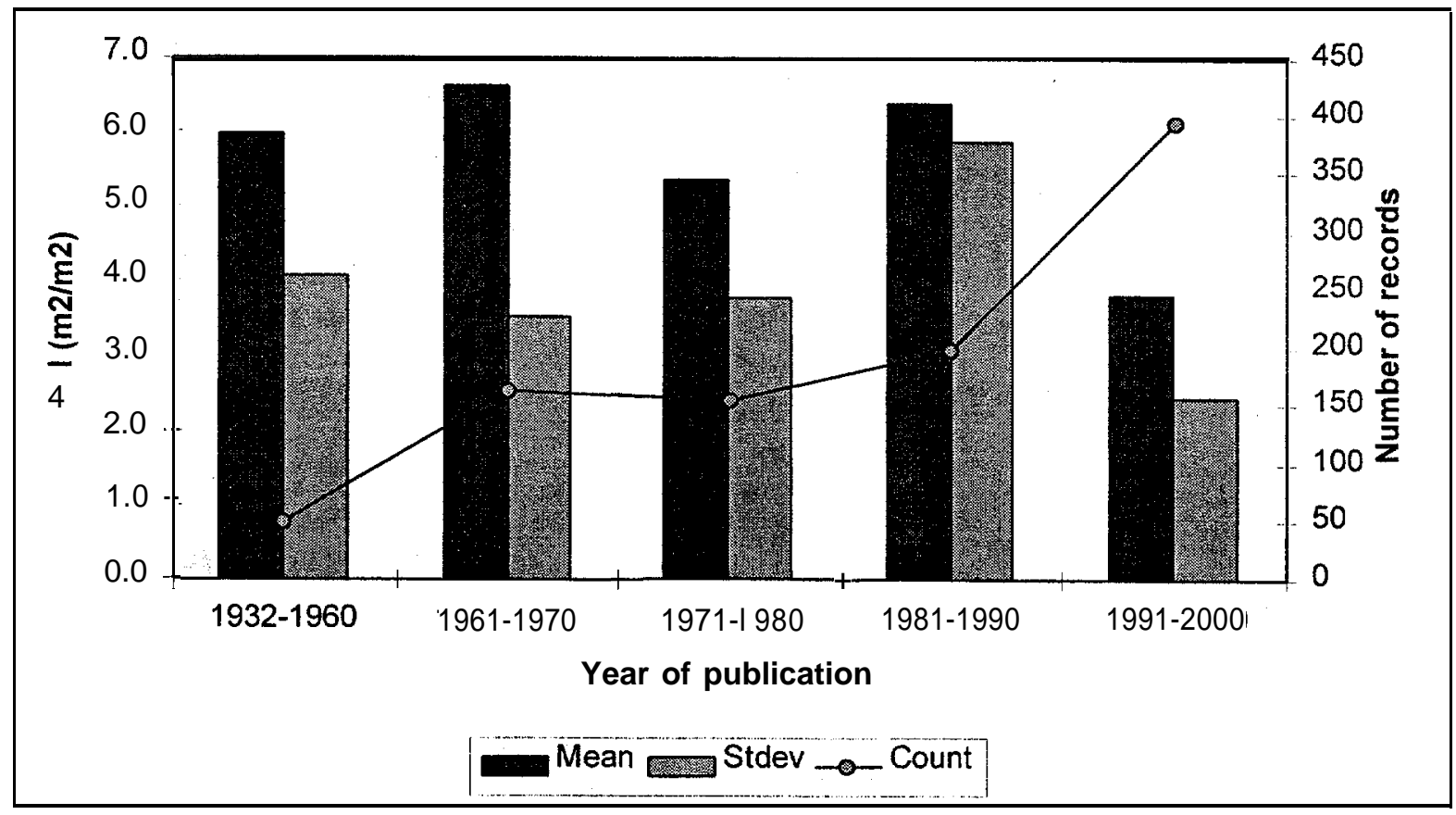

Fig. 3. Distribution of reported LAI values, classified by decade of publication, 


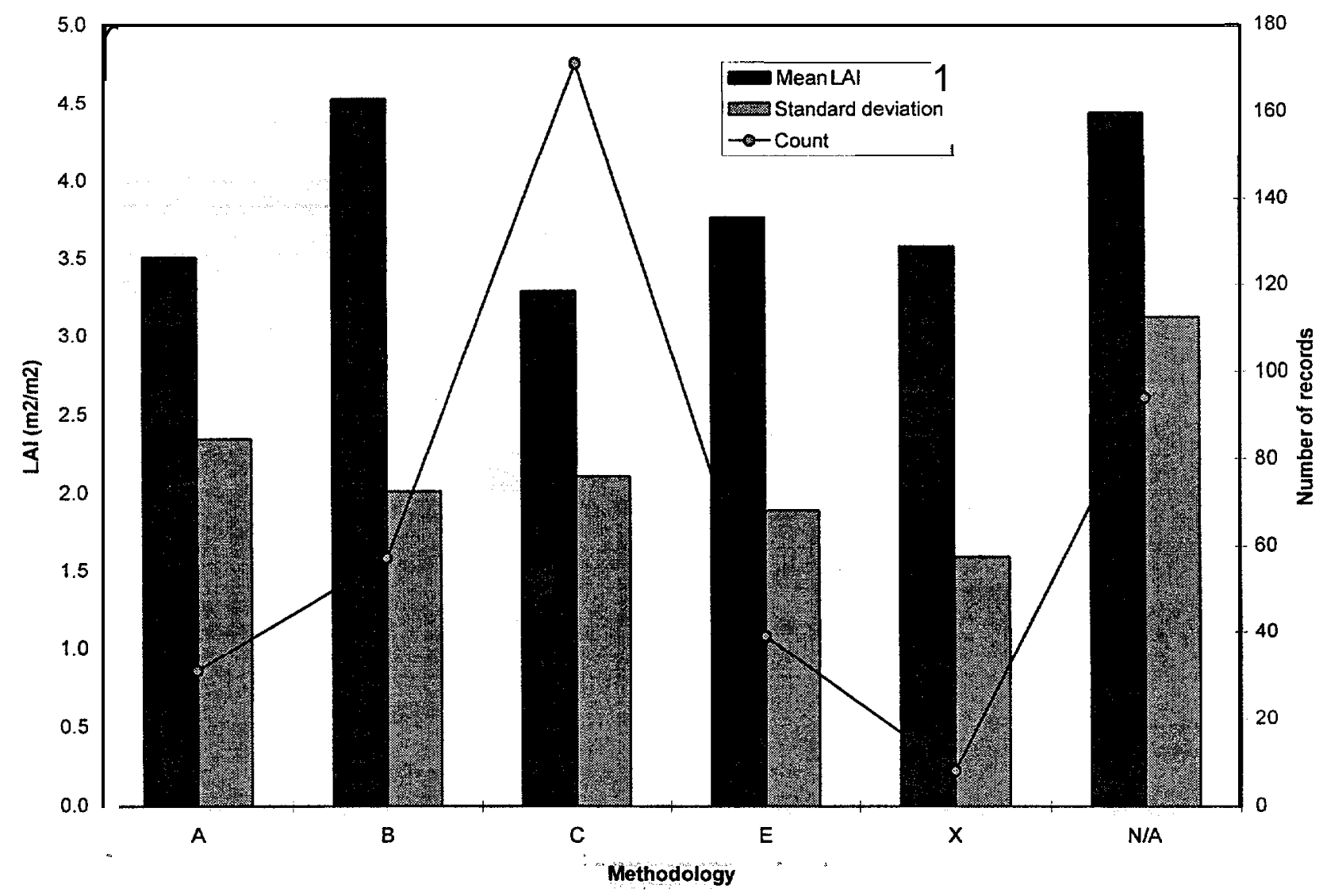

Fig. 4. Distribution'of LAI data published in the decade 1991-2000, plotted by estimation methodology. Where a combination of methods was used, only the principal method is tallied. A, Destructive harvest; B, Litterfall; C, Allometry; E, Indirect noncontact (LAI-2000 or other); X, Unknown (i.e., literature was checked and method was not specified); N/A, Not available (i.e., literature was not available for checking). 


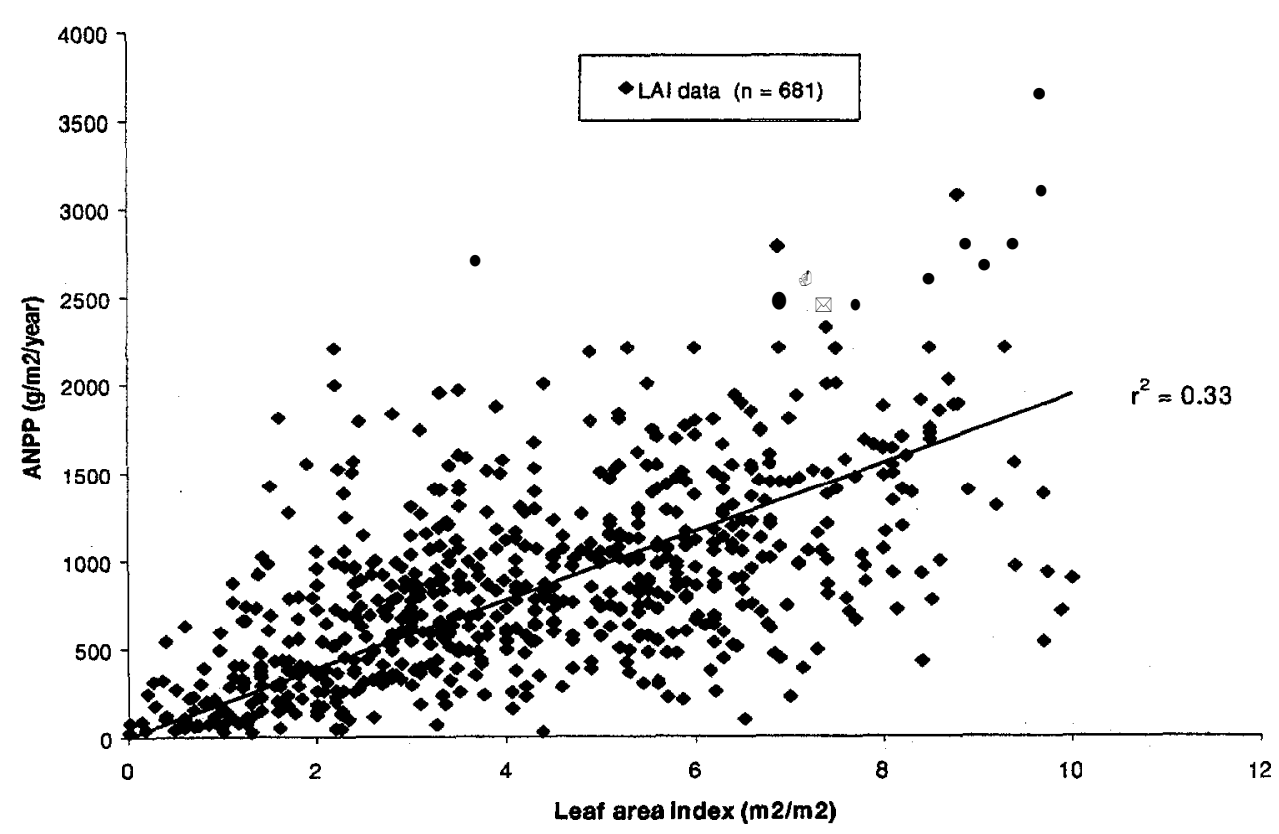

Fig. 5. ANPP as a function of LAI for a subset of the data for which both parameters were available.

As a further data-checking exercise, a common statistical outlier analysis was used to determine LAI data values that were unlikely to be accurately reported, either in measurement or in recording of the data (Sokal and Rohlf 1981). The interquartile range (IQR) approach is a nonparametric analytical method that identifies outliers via a detailed statistical determination of a data distribution. The data were first ranked from lowest numerical value to highest, and the median and quartiles of the data set were determined. Statistical outliers were then defined as those data values that lie beyond an "inner fence," which is defined by

$$
\mathrm{x}<\mathrm{F}_{1}+1.5(\mathrm{IQR}) \quad \text { or } \quad \mathrm{x}>\mathrm{F}_{3}-1.5(\mathrm{IQR}),
$$

where $F_{1}$ and $F_{3}$ are the first and third quartiles and $\quad \mathrm{IQR}=\mathrm{F}_{3}-\mathrm{F}_{1}$.

The outlier analysis indicated that a total of 53 statistically improbable values occurred throughout the entire data set (Table 6). The global mean LAI value was subsequently decreased from 5.23 to 4.51 following the outlier analysis. More importantly, the global maximum LAI value fell from 47.0 to 12.1 (or 15.0, when biomes were considered individually). Of the 15 biomes, 6 had no statistical outliers, partly because of the conservative nature of the IQR method (Sokal and Rohlf 1981). Other more aggressive approaches, such as Grubbs' Method (Grubbs 1969) could have produced additional outliers for flagging or potential removal from the data set.

Several biomes had statistical outliers that, when removed, resulted in significant changes in mean, minimum, and maximum LAI values (Table 6). The boreal and temperate deciduous broadleaf biomes showed notable decreases in maximum LAI values following the analysis, although the mean values for these biomes were not significantly changed. In contrast, the IQR 
analysis removed three outliers from the grassland biome data set, which resulted in a drastic decrease of the maximum reported LAI value from 15.4 to 5.0 and a subsequent decrease in mean LAI from 2.5 to 1.7 (Table 6). Likewise, the temperate evergreen needleleaf biome experienced a drop in maximum LAI from 47.0 to 15.0 and a fall in mean LAI from 6.70 to 5.47. Overall, the IQR outlier analysis served mostly'to remove very high LAI values, which occasionally led to decreases in the mean LAI value reported for a biome. 
Table 5. Extended list of land validation sites for satellite remote sensing, matched to nearest sites from the Worldwide Historical LAI data set (this study)

Cross-referencing was possible for 29 out of the list of 40 sites, in many cases for the same type of biome/vegetation cover. List of sites based on NASA Earth Observing System (EOS) LAI Meeting, Frascati, Italy, June 2001.

\begin{tabular}{|c|c|c|c|c|c|c|c|c|c|}
\hline \multicolumn{2}{|c|}{$\begin{array}{c}\text { Extended list of EOS land } \\
\text { validation sites }\end{array}$} & \multirow[b]{2}{*}{ Biome } & \multirow[b]{2}{*}{ Lat (dd) } & \multirow[b]{2}{*}{ Long (dd) } & \multirow[b]{2}{*}{ LAl site name } & \multirow[b]{2}{*}{ Biome/cover } & \multicolumn{3}{|c|}{ Nearest historic LAI sites } \\
\hline Validation site name & Country & & & & & & Lat & Long & LAI historic \\
\hline $\begin{array}{l}\text { ARM/CART-Ponca } \\
\text { City }\end{array}$ & OK, USA & Cropland & 36.750 & -97.083 & $\begin{array}{l}\text { ARM-CART, } \\
\text { Ponca, OK }\end{array}$ & Cropland/wheat & 36.75 & -97.08 & 7.50 \\
\hline ARM/CART & OK, USA & Cropland & 36.770 & -97.130 & & & & & \\
\hline ARM/CART-Shilder & OK, USA & & 36.850 & -96.683 & & & & & \\
\hline ARM/CART-SGP & OK, USA & Grass/crop & 36.640 & -97.500 & & & & & \\
\hline $\begin{array}{l}\text { ARM/CART-Little } \\
\text { Washita }\end{array}$ & OK, USA & & 34.960 & -97.979 & $\begin{array}{l}\text { Johnson and } \\
\text { Risser ( 1974) }\end{array}$ & Forest/TeDBL & 35.25 & -97.33 & 4.80 \\
\hline BARC/USDA-ARS & MD, USA & $\begin{array}{l}\text { Crop/decid } \\
\text { forest }\end{array}$ & 39.030 & -76.850 & $\begin{array}{l}\text { Georgetown, } \\
\text { DE }\end{array}$ & Cropland/beans & 38.70 & -75.30 & $\begin{array}{l}\text { Range } 0.90-2.50 \\
\text { (days 38-69) }\end{array}$ \\
\hline Barton Bendish & UK & Cropland & 52.617 & 0.527 & $\begin{array}{l}\text { Sutton } \\
\text { Bonington }\end{array}$ & Wheat & 52.83 & -1.25 & $5.52 \pm 1.42(\mathrm{n}=5)$ \\
\hline Bondville & IN, USA & Cropland & 40.007 & -88.291 & $\begin{array}{l}\text { Lincoln, NE } \\
\text { Kansas }\end{array}$ & $\begin{array}{l}\text { Wheat/soybean } \\
\text { Wheat }\end{array}$ & $\begin{array}{l}40.48 \\
39.15\end{array}$ & $\begin{array}{l}-96.40 \\
-96.62\end{array}$ & $\begin{array}{l}2.70 / 3.20(\mathrm{n}=2) \\
1.50 / 3.50(\mathrm{n}=2)\end{array}$ \\
\hline BOREAS NSA & Canada & $\begin{array}{l}\text { Conif } \\
\text { forest }\end{array}$ & 55.880 & -98.481 & $\begin{array}{l}\text { BOREAS } \\
\text { NSA }\end{array}$ & Forest/BoENL & $\begin{array}{r}55.75 \\
-55.92\end{array}$ & $\begin{array}{r}-97.69 \\
99.03\end{array}$ & $3.08 \pm 2.47(n=13)$ \\
\hline BOREAS SSA & Canada & $\begin{array}{l}\text { Conif } \\
\text { forest }\end{array}$ & 53.656 & -105.323 & BOREAS SSA & Forest/BoENL & 53.59 & $\begin{array}{l}-104.73- \\
106.20\end{array}$ & $3.45 \pm 3.21(n=6)$ \\
\hline $\begin{array}{l}\text { Brasschaat (De } \\
\text { Inslag) }\end{array}$ & Belgium & & 51.300 & 4.517 & Various & Forest/TeDBL & $\begin{array}{r}50.03 \\
-50.18\end{array}$ & $\begin{array}{l}4.35- \\
5.23\end{array}$ & $6.00 \pm 1.88(n=5)$ \\
\hline $\begin{array}{l}\text { Cascades/HJ } \\
\text { Andrews }\end{array}$ & OR, USA & $\begin{array}{l}\text { Conif } \\
\text { forest }\end{array}$ & 44.249 & -122.180 & $\begin{array}{l}\text { Andrews Exp. } \\
\text { Forest, OR }\end{array}$ & Forest $/$ TeENL & 44.25 & -122.33 & 12.50 \\
\hline Cascades/Old Pine & OR, USA & $\begin{array}{l}\text { Conif } \\
\text { forest }\end{array}$ & 44.499 & -121.624 & $\begin{array}{l}\text { Oregon Gholz } \\
\text { plot VI (pine) }\end{array}$ & Forest/TeENL & 44.50 & -121.50 & 7.00 \\
\hline $\begin{array}{l}\text { Cascades/Young } \\
\text { Pine }\end{array}$ & OR, USA & $\begin{array}{l}\text { Conif } \\
\text { forest }\end{array}$ & 44.417 & -121.567 & $\begin{array}{l}\text { OTTER } \\
\text { Metolius } \\
\text { control (pine) }\end{array}$ & Forest/TeENL & 44.25 & -121.75 & 0.80 \\
\hline Harvard Forest & MA, USA & $\begin{array}{l}\text { Decid } \\
\text { forest }\end{array}$ & 42.538 & -72.171 & Asner (1998) & Forest/TeDBL & 42.50 & -72.20 & $3.20-5.50$ \\
\hline Howland & ME, USA & $\begin{array}{l}\text { Conif } \\
\text { forest }\end{array}$ & 45.200 & -68.733 & & & & & $\begin{array}{l}\text { No sites; } \pm 1.0 \text { degree } \\
\text { lat }\end{array}$ \\
\hline
\end{tabular}


Table 5 (continued)

\begin{tabular}{|c|c|c|c|c|c|c|c|c|c|}
\hline \multicolumn{2}{|c|}{$\begin{array}{c}\text { Extended list of EOS land } \\
\text { validation sites }\end{array}$} & \multirow[b]{2}{*}{ Biome } & \multirow[b]{2}{*}{ Lat (dd) } & \multirow[b]{2}{*}{ Long (dd) } & \multirow[b]{2}{*}{ LAI site name } & \multirow[b]{2}{*}{ Biome/cover } & \multicolumn{3}{|c|}{ Nearest historic LAI sites } \\
\hline Validation site name & Country & & & & & & Lat & Long & LAI historic \\
\hline Ji Parana/Jaru & Brazil & $\begin{array}{l}\text { Trop BL } \\
\text { forest }\end{array}$ & -10.083 & -61.931 & & & & & $\begin{array}{l}\text { No sites; } \pm 1.00 \\
\text { degree lat }\end{array}$ \\
\hline Jornada LTER & NM, USA & $\begin{array}{l}\text { Shrub/ } \\
\text { woodland }\end{array}$ & 32.607 & -106.870 & $\begin{array}{l}\text { Jornada LTER, } \\
\text { NM }\end{array}$ & Grass/shrub & 32.52 & -106.80 & Range $0.80-3.90$ \\
\hline Jrvselja & Estonia & $\begin{array}{l}\text { Boreal } \\
\text { forest }\end{array}$ & 58.260 & 27.300 & & & & & $\begin{array}{l}\text { No sites; } \pm 1.00 \\
\text { degree lat }\end{array}$ \\
\hline $\begin{array}{l}\text { Kejimkujik Park, } \\
\text { Nova Scotia }\end{array}$ & Canada & $\begin{array}{l}\text { Decid } \\
\text { forest }\end{array}$ & 44.500 & -65.500 & $\begin{array}{l}\text { Fundy Model } \\
\text { Forest }\end{array}$ & Forest/TeMXD & 45.43 & -65.31 & 8.60 \\
\hline Konza & KS, USA & Grassland & 39.082 & -96.560 & Konza & Grassland & 39.10 & -96.61 & $0.30-3.50$ \\
\hline Krasnoyarsk & Russia & $\begin{array}{l}\text { Boreal } \\
\text { forest }\end{array}$ & 57.270 & 91.600 & & & & & $\begin{array}{l}\text { No sites; } \pm 1.00 \\
\text { degree lat }\end{array}$ \\
\hline Landes & France & $\begin{array}{l}\text { Conif } \\
\text { forest }\end{array}$ & 44.567 & -1.033 & & & & & $\begin{array}{l}\text { No sites; } \pm 1.00 \\
\text { degree lat }\end{array}$ \\
\hline Mali & Mali & Shrubland & 15.333 & -1.533 & & & & & $\begin{array}{l}\text { No sites; } \pm 1.00 \\
\text { degree lat }\end{array}$ \\
\hline Mandalgobi & Mongolia & Grass/crop & 45.995 & 106.327 & $\begin{array}{l}\text { Zhao (1994) } \\
\text { [CHINA] }\end{array}$ & Forest/TeMXD & 45.00 & 127.00 & $4.65 \pm 2.01(n=8)$ \\
\hline \multirow[t]{2}{*}{ Maricopa } & AZ, USA & $\begin{array}{l}\text { Crop/decid } \\
\text { forest }\end{array}$ & 33.070 & -111.970 & $\begin{array}{l}\text { Whittaker and } \\
\text { Niering (1975) }\end{array}$ & Woodland & 32.50 & -111.00 & $2.22 \pm 1.02(n=4)$ \\
\hline & & & & & $\begin{array}{l}\text { Whittaker and } \\
\text { Niering(1975) }\end{array}$ & Forest/TeMXD & 32.50 & -111.00 & $10.88 \pm 5.14(n=8)$ \\
\hline Maun & Botswana & Woodland & -19.923 & 23.594 & & & & & $\begin{array}{l}\text { No sites; } \pm 1.00 \\
\text { degree lat }\end{array}$ \\
\hline Mongu & Zambia & Woodland & -15.438 & 23.253 & & & & & $\begin{array}{l}\text { No sites; } \pm 1.00 \\
\text { degree lat }\end{array}$ \\
\hline NTL LTER & WI, USA & $\begin{array}{l}\text { Conif } \\
\text { forest }\end{array}$ & 45.946 & -89.600 & $\begin{array}{l}\text { Price County, } \\
\text { WI }\end{array}$ & Forest/TeENL & 45.90 & -90.20 & $2.40 / 3.10(n=2)$ \\
\hline Okwa River & Botswana & Shrubland & -22.409 & 21.713 & & & & & $\begin{array}{l}\text { No sites; } \pm 1.0 \text { degree } \\
\text { lat }\end{array}$ \\
\hline Pandamentanga & Botswana & Woodland & -18.655 & 25.500 & & & & & $\begin{array}{l}\text { No sites; } \pm 1.0 \text { degree } \\
\text { lat }\end{array}$ \\
\hline Park Falls & WI, USA & $\begin{array}{l}\text { Decid } \\
\text { forest }\end{array}$ & 45.946 & -90.272 & $\begin{array}{l}\text { Fassnacht and } \\
\text { Gower (1997) }\end{array}$ & Forest/TeDBL & $\begin{array}{l}45.70- \\
46.10\end{array}$ & $\begin{array}{l}88.90- \\
90.20\end{array}$ & $5.70 \pm 1.32(n=15)$ \\
\hline
\end{tabular}


Table 5 (continued)

\begin{tabular}{|c|c|c|c|c|c|c|c|c|c|}
\hline \multicolumn{2}{|c|}{$\begin{array}{c}\text { Extended list of EOS land } \\
\text { validation sites }\end{array}$} & \multirow[b]{2}{*}{ Biome } & \multirow[b]{2}{*}{ Lat (dd) } & \multirow[b]{2}{*}{ Long (dd) } & \multirow[b]{2}{*}{ LAI site name } & \multirow[b]{2}{*}{ Biome/cover } & \multicolumn{3}{|c|}{ Nearest historic LAI sites } \\
\hline Validation site name & Country & & & & & & Lat & Long & LAI historic \\
\hline Podkamennaya & Russia & $\begin{array}{l}\text { Boreal } \\
\text { forest }\end{array}$ & 61.500 & 92.500 & $\begin{array}{l}\text { Schulze et al. } \\
\text { (1995) }\end{array}$ & Forest/BoDNL & 60.85 & 128.27 & $1.03-5.70(\mathrm{n}=3)$ \\
\hline Romilly & France & Cropland & 48.433 & 3.800 & Fontainebleu & Forest/TeDBL & 48.43 & 2.68 & $4.32 \pm 2.20(n=5)$ \\
\hline Ruokolahti & Finland & $\begin{array}{l}\text { Conif } \\
\text { forest }\end{array}$ & 61.533 & 28.700 & South Karelia & Forest/BoENL & 62.00 & 34.00 & $3.06 \pm 0.82(n=17)$ \\
\hline SALSA San Pedro & AZ, USA & $\begin{array}{l}\text { Shrub/ } \\
\text { woodland }\end{array}$ & 31.740 & -109.850 & $\begin{array}{l}\text { Whittaker and } \\
\text { Niering (1975) }\end{array}$ & Desert & 32.50 & -110.75 & $0.93 \pm 0.46(n=4)$ \\
\hline Sevilletta LTER & NM, USA & Grass/crop & 34.344 & -106.671 & Sevilletta & Shrubland & 34.35 & -106.88 & Range $0.80-1.90$ \\
\hline $\begin{array}{l}\text { Skukuza, Kruger } \\
\text { N.P. }\end{array}$ & $\begin{array}{l}\text { South } \\
\text { Africa }\end{array}$ & Savanna & -25.020 & 31.497 & Nylsvley & Grass/savanna & -24.60 & 28.70 & $0.78 \pm 0.16(n=5)$ \\
\hline Tapajos/Santarem & Brazil & $\begin{array}{l}\text { Tropfor } \\
\text { (primary) }\end{array}$ & -2.857 & -54.960 & Tapajos & Forest $/ \mathrm{TrEBL}$ & -3.5 & -55.3 & Range $3.80-7.10$ \\
\hline Tapajos/Santarem & Brazil & $\begin{array}{l}\text { Tropfor } \\
\text { (logged) }\end{array}$ & -3.017 & -54.971 & & & & & \\
\hline Tapajos/Santarem & Brazil & $\begin{array}{l}\text { Trop } \\
\text { pasture }\end{array}$ & -3.020 & -54.889 & Tapajos & Pasture & -3.20 & -54.60 & Range $0.25-9.10$ \\
\hline Tshane & Botswana & Savanna & -24.164 & 21.893 & & & & & $\begin{array}{l}\text { No sites; } \pm 1.00 \\
\text { degree lat }\end{array}$ \\
\hline Uardry, NSW & Australia & Grass/crop & -34.390 & 145.300 & $\begin{array}{l}\text { Kioloa State } \\
\text { Forest }\end{array}$ & Forest/TeEBL & -35.35 & 150.18 & $3.12 \pm 1.00(\mathrm{n}=13)$ \\
\hline $\begin{array}{l}\text { Virginia Coast } \\
\text { Reserve }\end{array}$ & VA, USA & $\begin{array}{l}\text { Crop/decid } \\
\text { forest }\end{array}$ & 37.500 & -75.670 & & & & & $\begin{array}{l}\text { No sites; } \pm 1.00 \\
\text { degree lat }\end{array}$ \\
\hline Walker Branch & TN, USA & $\begin{array}{l}\text { Decid } \\
\text { forest }\end{array}$ & 35.958 & -84.288 & $\begin{array}{l}\text { Walker } \\
\text { Branch/Oak } \\
\text { Ridge }\end{array}$ & Forest/TeDBL & 35.96 & -84.29 & $5.03 \pm 0.12(\mathrm{n}=3)$ \\
\hline $\begin{array}{l}\text { Watson Lake, } \\
\text { Yukon }\end{array}$ & Canada & $\begin{array}{l}\text { Conif } \\
\text { forest }\end{array}$ & 60.100 & -128.800 & & & & & $\begin{array}{l}\text { No sites; } \pm 1.00 \\
\text { degree lat }\end{array}$ \\
\hline Zotino & Russia & $\begin{array}{l}\text { Boreal } \\
\text { forest }\end{array}$ & 61.000 & 90.000 & & & & & $\begin{array}{l}\text { No sites; } \pm 1.00 \\
\text { degree lat }\end{array}$ \\
\hline
\end{tabular}


Table 6. Statistical distribution of LAI by biome, for the original data compilation, and after removal of outliers following Inter-Quartile Range (IQR) statistical analysis

- Of the original total of 1008 records, 77 were excluded from this analysis (e.g., because biome was not available). See Table 1(b) for biome acronyms.

\begin{tabular}{|c|c|c|c|c|c|c|c|c|c|c|}
\hline \multicolumn{4}{|c|}{ Original data } & \multicolumn{7}{|c|}{-Number of Data âfter IQR analysis } \\
\hline Biome & $\begin{array}{c}\text { Number of } \\
\text { observations }\end{array}$ & Mean & $\begin{array}{l}\text { Standard } \\
\text { deviation }\end{array}$ & Min & Max & $\begin{array}{l}\text { outliers } \\
\text { removed }\end{array}$ & Mean & $\begin{array}{l}\text { Standard } \\
\text { deviation }\end{array}$ & Min & Max \\
\hline All & 931 & 5.23 & 4.08 & 0.002 & 47.0 & 53 & 4.51 & 2.52 & 0.002 & 12.1 \\
\hline Forest / BoDBL & 58 & 2.64 & 1.03 & 0.28 & 6.0 & 5 & 2.58 & 0.73 & 0.6 & 4.0 \\
\hline Forest / BoENL & 94 & 3.50 & 3.34 & 0.48 & 21.6 & 8 & 2.65 & 1.31 & 0.48 & 6.21 \\
\hline Crops & 88 & 4.22 & 3.29 & 0.2 & 20.3 & 5 & 3.62 & 2.06 & 0.2 & 8.7 \\
\hline Desert & 6 & 1.31 & 0.85 & 0.59 & 2.84 & 0 & 1.31 & 0.85 & 0.59 & 2.84 \\
\hline Grassland & 28 & 2.50 & 2.98 & 0.29 & 15.4 & 3 & 1.71 & 1.19 & 0.29 & 5.0 \\
\hline Plantation & 77 & 8.72 & 4.32 & 1.55 & 18.0 & 0 & 8.72 & 4.32 & 1.55 & 18.0 \\
\hline$\cdots \quad=$ & 5 & 2.08 & 1.58 & 0.4 & 4.5 & 0 & 2.08 & 1.58 & 0.4 & 4.5 \\
\hline Forest / BoTeDNL & 17 & 4.63 & 2.37 & 0.5 & 8.5 & 0 & 4.63 & 2.37 & 0.5 & 8.5 \\
\hline Forest / TeDBL & 187 & 5.12 & 1.84 & 0.4 & 16.0 & 3 & 5.06 & 1.60 & 1.1 & 8.8 \\
\hline Forest / TeEBL & 58 & 5.82 & 2.57 & 0.8 & 12.5 & 1 & 5.70 & 2.43 & 0.8 & 11.6 \\
\hline Forest / TeENL & 215 & 6.70 & 5.95 & 0.002 & 47.0 & 16 & $5.47^{\circ}$ & 3.37 & $0.002^{\prime}$ & 15.0 \\
\hline Forest / TrDBL & 18 & 3.92 & 2.53 & 0.6 & $8.9^{-}$ & 0 & $3.92^{\infty}$ & 2.53 & 0.6 & 8.9 \\
\hline Forest / TrEBL & 61 & 4.90 & 1.95 & 1.48 & 12.3 & 1 & 4.78 & 1.70 & 1.48 & 8.0 \\
\hline Tundra & 13 & 2.69 & 2.39 & 0.18 & 7.2 & 2 & 1.88 & 1.47 & 0.18 & 5.3 \\
\hline Wetlands & 6 & 6.34 & $2.29^{\circ}$ & 2.50 & 8.4 & 0 & 6.34 & 2.29 & 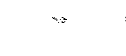 & 8.4 \\
\hline
\end{tabular}




\section{DISCUSSION}

At the present time, about $1000 \mathrm{LAI}$ records are available for an estimated 400 unique field sites, together with associated variables such as latitude/longitude, elevation, stand age, aboveground NPP, etc. This data compilation attained its target-it was originally estimated that around 1000 distinct LAI measurements worldwide might be available from the scientific literature-and a possible further 500 to 1000 data points have been identified by the authors. However, we are aware that certain kinds of biome/land cover types are under-represented in this data set-deserts, wetlands, and shrublands are particularly lacking, suggesting a need for directed field work in the future.

Modeling and EOS satellite product validation both require field measurements to constrain LAI values for different biomes (typical minimum and maximum values, phenology, etc.). The value of this kind of historical data set lies in providing realistic ranges by biome/land cover type for comparison with newly collected data. A data point for MODIS validation is better than nothing, even with imperfect ancillary information! (Running, S. W., University of Montana, personal communication, December 1998). Maximum values for point measurements are unlikely to be exceeded or even approached for spatially weighted LAI, which is what satellites and truly spatial models are measuring or modeling. As the size of the sample area increases, the range of LAI found for a particular biome or land cover type (particularly its maximum value) will decrease. Thus, large areas $\left(1 \mathrm{~km}^{2}\right.$ or more) are unlikely to ever have LAI greater than 5 , although LAI from field plots may exceed 8 or even 10 in some cases. Our global outlier analysis suggests that LAI values in excess of 12 do not appear to fit in this worldwide historical data set, a view which is supported by expert opinion (Waring, R. H., Oregon State University, personal communication, October 2001).

LAI in needleleaf canopies stands out from all other vegetation cover types-some of these include all-sided LAI, which is clearly a different parameter from one-sided broadleaf LAI-but even needleleaf projected LAI is not really the same thing. Older estimates of needleleaf LAI obtained using allometric equations tend to be biased by the larger, open-grown trees used to develop the relationships between foliage mass and tree diameter (Waring, R. H, Oregon State University, personal communication, October 200 1). Indirect noncontact (optical) LAI estimates (e.g., LAI-2000) may be comparable with destructive harvesting or allometry for broadleaf canopies, but in needleleaf canopies it appears that a "clumping factor" also has to be taken into account (see Chen et al. 1997, Section 3). Such techniques estimate an "effective" LAI which may be an underestimate when foliage in the canopy is non-randomly distributed or clumped (Gower et al. 1999).

The vast majority of these field-based LAI data are from small sample plots (typically 0.2 ha in size or less, but many studies do not clearly report the number of samples or their spatial extent). Such data represent the LAI of individual canopies and/or canopy clusters. However, as the integrated area of the measurements increases, the reported LAI decreases because the fractional cover of the canopies becomes a contributing factor:

pixel or grid cell LAI, spatially weighted = plant LAI * fractional canopy cover 
A small number of field studies have worked along homogenous transects, and a very few studies have actually addressed the issue of scaling-up. For example, the Bigfoot initiative (formerly MODLERS) is addressing the topic of scaling from point field measurements to the relatively coarse resolution of satellite products, by measuring and scaling-up LAI and other parameters for $5 \mathrm{~km} * 5 \mathrm{~km}$ grids (based on 25-meter and 1000-meter cells) around four flux tower sites in North America.

\section{DATA AVAILABILITY}

\subsection{ORNL DISTRIBUTED ACTIVE ARCHIVE CENTER FOR BIOGEOCHEMICAL DYNAMICS}

The LAI data are maintained and distributed by the ORNL Distributed Active Archive Center (DAAC) for Biogeochemical Dynamics (http://www.daac.ornl.gov). The DAAC provides information about the Earth's biogeochemical dynamics to the global-change research community, policymakers, educators, and the interested general public. The ORNL DAAC is part of the Earth Observing System Data and Information System Project of the National Aeronautics and, Space Administration (NASA), which forms an integral part of NASA's contribution to the U.S. Global Change Research Program. For information about this data set and others, the DAAC User Services staff may be contacted at

\section{ORNL DAAC}

Oak Ridge National Laboratory

Telephone: 1-865- 241-3952

Fax: 1-865-574-4665

Email: ornldaac@ornl.gov

\subsection{CAUTIONS IN USING THE DATA}

Creating a single compilation of LAI data for this large number of sites required certain assumptions and conversions that may not be universally applicable to all sites. Some of the sites in this data set are agricultural sites, and others may represent natural systems with management treatments, such as fertilizer, irrigation, grazing, burning, or thinning. Where possible, we have tried to indicate uncertainties or unusual treatments. Detailed descriptions of the study sites, sampling methods, and, the method of estimating LAI are available only in the original literature. Therefore the inclusion of points in this data set is no guarantee that the LAl values are strictly comparable. The data should be regarded as illustrating the range of LAI for natural and managed ecosystems worldwide. However, we anticipate that users may find this data set useful as an index to select more detailed LAI site data, or that they may select a subset of these data for their use. Users of this synthesis are strongly encouraged to check the primary literature prior to using these data. 


\section{REFERENCES}

Asner, G. P. 1998. Biophysical and biochemical sources of variability in canopy reflectance. Remote Sens. Environ. 64:234-53.

Barclay, H. J. 1998. Conversion of total leaf area to projected leaf area in lodgepole pine and Douglas-fir. Tree Physiol. 18: 185-93.

Beadle, C. L. 1993. Growth analysis. pp. 36-46. In D. 0. Hall et al. (eds.), Photosynthesis and Production in a Changing Environment: A Field and Laboratory Manual. Chapman and Hall, London.

Chen, J. M. 1996. Optically-based methods for measuring seasonal variation in leaf area index in boreal conifer stands. Agric. For. Meteorol. 80: 13 5-63.

Chen, J. M., and T. A. Black. 1992. Defining leaf area index for non-flat leaves. Plant Cell Environ. 15:421-29.

Chen, J. M., and J. Cihlar. 1995. Quantifying the effect of canopy architecture on optical measurements of leaf area index using two gap size analysis methods. IEEE Trans. Geosci. Remote Sens. 33:777-87.

Chen, J. M., and J. Cihlar. 1996. Retrieving leaf area indexes of boreal conifer forests using Landsat TM images. Remote Sens. Environ. 55:153-162.

Chen, J. M., P. M. Rich, S. T. Gower, J. M. Norman, and S. Plummer. 1997. Leaf area index of boreal forests: Theory, techniques, and measurements. J. Geophys. Res.-Atmosph. 102:29429-43.

Deblonde, G., M. Penner, and A. Royer. 1994. Measuring leaf area index with the Li-COR LAI2000 in pine stands. Ecology 75: 1507-I 1.

Esser, G., H. F. H. Lieth, J. M. 0. Scurlock, and R. J. Olson. 1997. Worldwide Estimates and Bibliography of Net Primary Productivity Derived from Pre- 1982 Publications. ORNL TM13485. Oak Ridge National Laboratory, Oak Ridge, Tenn.

Gower, S. T., C. J. Kucharik, and J. M. Norman. 1999. Direct and indirect estimation of leaf area index, $f_{A P A R}$, and net primary production of terrestrial ecosystems. Remote Sens. Environ. 70:2951.

Grubbs, F. E. 1969. Procedures for detecting outlying observations in samples. Technometrics $11: 1-21$

Johnson, F. L., and P. G. Risser. 1974. Biomass, annual net primary production, and dynamics of six mineral elements in a post oak-blackjack oak forest. Ecology 55:1246-58.

Kucharik, C. J., J. M. Norman, and S. T. Gower. 1998. Measurements of branch area and adjusting leaf area index indirect measurements. Agric. For. Meteorol. 91:69-88. 
McWilliam, A. L. C., J. M. Roberts, 0. M. R. Cabral, M. V. B. R. Leitao, A. C. L. Decosta, G. T. Maitelli, and C. A. G. P. Zamparoni. 1993. Leaf-area index and aboveground biomass of terrafirme rain-forest and adjacent clearings in Amazonia. Funct. Ecol. 7:310-1 7.

Norby, R. J., D. E. Todd, J. Fults, and D. W. Johnson. 2001. Allometric determination of tree growth in a CO2-enriched sweetgum stand. New Phytol. 150:477-87.

Norman, J. M., and G. S. Campbell. 1989. Canopy structure. pp. 301-25. In R. W. Pearcy et al. (eds.), Plant Physiological Ecology: Field Methods and Instrumentation. Chapman and Hall, London.

Olson, R. J., K. R. Johnson, D. L. Zheng, and J. M. 0. Scurlock. 2001. Global and Regional Ecosystem Modeling: Databases of Model Drivers and Validation Measurements. ORNL/TM2001/1 96. Oak Ridge National Laboratory, Oak Ridge, Tenn.

Running, S. W., and J. C. Coughlan. 1988. A general model of forest ecosystem processes for regional applications. I. Hydrologic balance, canopy gas exchange, and primary production processes. Ecol. Modell. 42:125-54.

Schulze, E. D. 1982. Plant life forms and their carbon, water, and nutrient relations. pp. 615-76. In Encyclopedia of Plant Physiology, New Series, Vol. 12B. Springer-Veriag, Berlin.

Schulze, E. D., W. Schulze, F. M. Kelliher, N. N. Vygodskaya, W. Ziegler, K. I. Kobak, H. Koch, A. Arneth, W. A. Kusnetsova, A. Sogatchev, A. Issajev, G. Bauer, and D. Y. Hollinger. 1995. Aboveground biomass and nitrogen nutrition in a chronosequence of pristine Dahurian Larix stands in eastern Siberia. Can. J. For. Res. 25:943-60.

Scurlock, J. M. O., W. Cramer, R. J. Olson, W. J. Parton, and S. D. Prince. 1999. Terrestrial NPP: Towards a consistent data set for global model evaluation. Ecol. Appl. 9:913-19.

Sellers, P., and D. S. Schimel. 1993. Remote-sensing of the land biosphere and biogeochemistry in the EOS era: Science priorities, methods, and implementation. Global Planet. Chg. 7:279-97.

Sokal, R. R., and F. J. Rohlf. 198 1. Biometry: Second Edition. Freeman, New York.

Waring, R. H. 1983. Estimating forest growth and efficiency in relation to canopy leaf area. Adv. Ecol. Res. 13:327-54.

Whittaker, R. H., and W. A. Niering. 1975. Vegetation of the Santa Catalina Mountains, Arizona. V. Biomass, production, and diversity along the elevation gradient. Ecology 56:771-90.

Zhao, H. 1994. Studies on biomass and productivity of main forest types in broadleaved korean pine forest region of Heilongjiang province. In: X. Zhou (ed.), Long-term Research on China's Forest Ecosystems. Northeast Forestry University Press, Harbin, China. 
*

$=$

*

* 


\section{INTERNAL DISTRIBUTION}

1. R.B. Cook

2. D. E. Fowler

3. P. J. Hanson

4. W. F. Harris

5. S. G. Hildebrand

6. M. A. Huston

7. G. K. Jacobs

8. A. W. King

9. G. Marland
10. R.J.Norby

11-15. R. J. Olson

16. W. M. Post

17-26. J. M. 0. Scurlock

27. L . D. Voorhees

28. S . Wullschleger

29. 'Central Research Library

30-32. ESD Library

33. Laboratory Records Department

34. Laboratory Records, ORNL-RC

\section{EXTERNALDISTRIBUTION}

35. Michael Apps, Department of Natural Resources, Canadian Forest Service, $5320122^{\text {nd }}$ Street, Edmonton, Alberta, T6H 3S5, Canada

36-45. Greg Asner, Department of Plant Biology, Carnegie Institution of Washington, Stanford, CA 94305

46. Dennis Baldocchi, Ecosystem Science Division and Berkeley Atmospheric Science Center, Department of Environmental Science, Policy, and Management, 151 Hilgard Hall, University of California, Berkeley, Berkeley, CA 94720

47. Richard Birdsey, Northern Global Change Research Program, USDA Forest Service, Newtown Square Corporate Campus, 11 Campus Boulevard, Suite 200, Newtown Square, PA 19073

48. Victor Brovkin, Climate Systems Research Department, Potsdam Institute for Climate Impact Research, P.O. Box 601203, 14412 Potsdam, Germany

49. Sandra Brown, Winrock International, 1621 N. Kent St., Suite 1200, Arlington, VA 22209

50. Wolfgang Buermann, Department of Geography, Boston University, 675 Commonwealth Avenue, Boston, MA'02215

51. Ingrid C. Burke, Department of Forest Sciences, 206 Natural Resources, Colorado State University, Fort Collins, CO 80523

52. John Vande Castle, University of New Mexico, 801 University Blvd SE, Suite 104, Albuquerque, NM 87106

53. Josef Cihlar, Canada Centre for Remote Sensing, Energy Mines and Resources Canada, 588 Booth Street, $4^{\text {th }}$ Floor, Ottawa, Canada K1A OY7

54. Warren Cohen, Forestry Sciences Laboratory, United States Forest Service, 3200 SW Jefferson Way, Corvallis, OR 97332 
55. Michael Coughenour, Natural Resources Ecology Laboratory, Colorado State University, Fort Collins, CO 80523

56. Wolfgang Cramer, Potsdam Institute for Climate Impact Research, P.O. Box 601203, Telegrafenberg, D- 144 12, Potsdam, Germany

57. Ken Day, Department of Natural Resources, Climate Impacts and Grazing Systems, 80 Meiers Road, Indooroopilly, Brisbane, Queensland, 4086, Australia

58. Ruth S. DeFries, Department of Geography, Rm.1127, Le Frak Hall, University of Maryland, College Park, MD 20742-8225

59. Gerd Esser, Institute for Plant Ecology, Justus-Liebig-University, Heinrich-Buff-Ring 38, D-35292 Giessen, Germany

60. Richard Fernandes, Canada Centre for Remote Sensing, 588 Booth St., Ottawa, Ontario K1A OY7, Canada

61. Christopher Field, Carnegie Institution of Washington, 290 Panama Street, Stanford, CA 94305

62. Jonathan A. Foley, Climate, People, and Environment Program, Institute for Environmental Studies, University of Wisconsin, 1225 West Dayton Street, Madison, WI 53706

63. Tagir Gilmanov, Department of Biology and Microbiology, South Dakota State University, Brookings, SD 57007

64. Scott Goetz, Department of Geography, University of Maryland, College Park, MD 20742-8225

65-74. Tom Gower, Department of Forest Ecology and Management, University of Wisconsin-Madison, 1630 Linden Drive, Madison, WI 53706

75. Kathy Hibbard, Climate Change Research Center, Institute for the Study of Earth, Oceans, and Space, University of New Hampshire, Morse Hall, 39 College Road, Durham, New Hampshire 03824-3525

76. Elisabeth Holland, Atmospheric Chemistry Division, National Center for Atmospheric Research, 1850 Table Mesa Drive, P.O. Box 3000, Boulder, CO 80307-3000

77. Robert B. Jackson, Department of Biology and Nicholas School of the Environment, Box 90340, Phytotron Building, Duke University, Durham, NC 27708

78. Paul Jarvis, Institute of Ecology and Resource Management, University of Edinburgh, Mayfield Road, Edinburgh EH9 3JU, UK

79. Jennifer Jenkins, Research Forester, USDA Forest Service, Northern. Global Change Program, 5 Radnor Corporate Center, Suite 200, 100 Matsonford Road, Radnor, PA 19087

80. Chris Justice, University of Virginia, Department of Environmental Science, Clark Hall, Charlottesville, VA 22903 
8 1. David Kicklighter, The Ecosystems Center, Marine Biological Laboratory, 7 MBL Street, Woods Hole, MA 02543

82. Chris Kucharik, Department of Soil Science, University of Wisconsin-Madison, 1525 Observatory Drive, Madison, WI 53706

83. William Lauenroth, Department of Range Science, NREL, Colorado State University, Fort Collins, CO 80523

84. Beverly E. Law, 328 Richardson Hall, College of Forestry, Oregon State University, Corvallis, OR 97331

85. Sune Linder, Department of Ecology and Environmental Research, Swedish University of Agricultural Sciences, P.O. Box 7072, S-75007 Uppsala, Sweden

86. Ross McMurtrie, School of Biological Science, University of New South Wales, Sydney 2052, Australia

87. Jeff Morisette, NASA GSFC, University of Maryland, Code 923, Greenbelt, MD 20771

88. Ranga Myneni, Department of Geography, Boston University, 675 Commonwealth Avenue, Boston, MA 02215

89. Ron Neilson, Forestry Sciences Laboratory, Oregon State University, Corvallis, OR 97331

90. Jian Ni, Max Planck Institute for Biogeochemistry, Carl Zeiss Promenade 10, P.O. Box 1001 64, D-07701 Jena, Germany

91. Office of Assistant Manager for Energy Research and Development, U.S. Department of Energy, Oak Ridge Operations, P.O. Box 2001, Oak Ridge, TN 3783 1-8600

92. Office of Scientific and Technical Information, P.O. Box 62, Oak Ridge, TN 37831

93. Dennis Ojima, Natural Resource Ecology Laboratory, Colorado State University, Fort Collins, CO 80523

94. Jerry S. Olson, 508 Eblen Cave Road, Lenoir City, TN 37771

95. William Pat-ton, Natural Resource Ecology Laboratory, Colorado State University, Fort Collins, CO S0523

96. Stephen D. Prince, Department of Geography, LeFrak Hall, University of Maryland, College Park, MD 20742-8225

97. Jeffrey L. Privette, NASA Biospheric Sciences, Code 923, Goddard Space Flight Center, Greenbelt, MD 20771

98. James Reichman, National Center for Ecological Analysis and Synthesis, 735 State Street, Suite 300, Santa Barbara, CA 9310 1-335 1 
99. Steve Running, School of Forestry, University of Montana, Missoula, MT 59812

100. David Schimel, Ecosystem Dynamics and the Atmosphere, Climate, and Global Dynamics Division, National Center for Atmospheric Research, Boulder, CO 80307

101. Robert Scholes, CSIR, P.O. Box 395, Pretoria 0001, South`Africa

102. Ernst-Detlef Schulze, Max-Planck-Institute for Biogeochemistry, Postbox IO 01 64, 07701 Jena, Germany

103. Hank Shugart, Department of Environmental Science, University of Virginia, Charlottesville, VA 22903

104. Philippe M. Teillet, Canada Centre for Remote Sensing, 588 Booth Street, Ottawa, Ontario, K1 A OY 7, Canada

105. Peter Thornton, Climate and Global Dynamics Division, National Center for Atmospheric Research, 1850 Table Mesa Drive, P.O. Box 3000, Boulder, CO 80307-3000

106. Yuhong Tian, Department of Geography, Boston University, 675 Commonwealth Avenue, Boston, MA 02215

107. Larry Tieszen, EROS Data Center, U.S. Geological Survey, Sioux Falls, SD 57198

108. David P. Turner, Forest Science Department, Oregon State University, Corvallis, OR 97331

109. Charles Vorosmarty, Complex System Research Center, University of New Hampshire, Durham, NH 03824

I10. Richard Waring, Department of Forest Science, College of Forestry, Oregon State University, Corvallis, OR 97331

11 1. Diane E. Wickland, Manager, Terrestrial Ecology Program, NASA Code YS, 300 E Street, SW, Washington. DC 20546

112. Curtis Woodcock. Department of Geography, Boston University, 675 Commonwealth Avenue, Boston, MA 02215

113. Daolan Zheng, Research Associate, Department of Geography, University of Maryland, College Park, MD 20742 